\title{
Chapter 16 \\ Research Democracy in a Randomized \\ Controlled Trial: Engaging Multiple \\ Stakeholders in Patient-Centered \\ Outcomes Research
}

\author{
Charlene Kuo, Christina Rush, Abigail Montero, Claudia Campos, \\ Gloria Elliott, Ivis Febus-Sampayo, Ysabel Duron, Migdalia Torres, \\ Margaret Darling, and Kristi D. Graves
}

\section{Introduction}

Patient-centered outcomes research (PCOR) addresses issues and measures outcomes that are meaningful to patients and other stakeholders. PCOR emphasizes involving patients and other interested stakeholder groups such as clinicians, advocates and caregivers in the research process [1-4]. Some funding agencies, such as the Patient-Centered Outcomes Research Institute (PCORI), require the "active incorporation of perspectives beyond those of the researchers" throughout the entire project [1]. Understanding factors that contribute to successful collaborations is a critical component to better serve our patient populations and forge stronger partnerships in PCOR. The involvement of engaged and enthusiastic team members with diverse perspectives is one of the factors important for PCOR.

C. Kuo - A. Montero - K. D. Graves $(\bowtie)$

Lombardi Comprehensive Cancer Center, Georgetown University, Washington, DC, USA

e-mail: Kristi.Graves@georgetown.edu

C. Rush

Department of Psychology, University of Colorado, Denver, CO, USA

C. Campos · G. Elliott

Nueva Vida, Inc., Alexandria, VA, USA

I. Febus-Sampayo

LatinaSHARE, New York, NY, USA

Y. Duron

The Latino Cancer Institute, San Jose, CA, USA

M. Torres

Gilda's Club New York City, New York, NY, USA

M. Darling

Humphrey School of Public Affairs, University of Minnesota, Minneapolis, MN, USA

(C) The Author(s) 2020

A. G. Ramirez, E. J. Trapido (eds.), Advancing the Science of Cancer in Latinos,

https://doi.org/10.1007/978-3-030-29286-7_16 
The benefits of engagement are demonstrated through the effective management of partnerships concerned with health and social welfare $[4,5]$. True engagement yields better work performance among team members. Improved work performance among teams is supported by creating an environment in which team members can fulfill and exceed expected roles and apply creativity to problem-solving to achieve or exceed the desired outcomes [4]. Similar contexts among health care teams can increase patient-centered care [6].

For teams conducting PCOR, one approach that may work to promote involvement among stakeholders with diverse perspectives and experiences is research democracy - a process in which individuals involved in research (e.g., team members, participants, advisors) have a vote and a voice in the decisions that are made and the procedures that are used to conduct the research. Elements of research democracy include opportunities for sharing opinions, casting votes, discussing outcomes, and identifying areas for improvement. We expand upon ideas presented in the limited literature on team engagement in PCOR [7-9] and provide examples of effective communication to keep each member updated and informed [9-11]. Research democracy can also provide a process for fostering creativity, innovation, and synergy among team members $[9,12,13]$.

The purpose of this chapter is to describe research democracy in a PCORIsponsored project, the Nueva Vida Intervention, and illustrate how such research democracy may promote PCOR. The literature on team engagement in research and public health interventions is limited [7-9]. To address these gaps, we present research democracy applications (Table 16.1), team member satisfaction (Table 16.2), barriers (Table 16.3), and benefits (Table 16.4) to conducting research in a PCOR context.

\section{Methods}

The Nueva Vida Intervention is a dyadic intervention that aimed to improve quality of life outcomes among Latina breast cancer survivors and their caregivers (PCORI AD12-11-5365) [14]. The Nueva Vida Intervention was evaluated in a randomized controlled trial, and the study team was composed of four community-based organizations (CBOs), scientific investigators from the Lombardi Comprehensive Cancer Center at Georgetown University, clinical and research consultants, an advisory board that included Latina cancer survivors and caregivers, and a data safety and monitoring board [14]. The intervention consisted of eight group-based sessions in which survivors and caregivers learned coping and communication skills in separate rooms and then joined together for discussion and a meal [14]. Throughout the process of study design, intervention refinement, protocol implementation, and follow-up, we collected data on team engagement through informal observations, direct discussions during team meetings, and survey assessments. 
Table 16.1 PCOR elements and research democracy approaches in the Nueva Vida Intervention project

\begin{tabular}{l|l}
\hline PCOR element & Research Democracy Approaches in the Nueva Vida Intervention \\
\hline Clear expectations & $\begin{array}{l}\text { - Maintained detailed records of every phone call and meeting } \\
{[9,11]}\end{array}$ \\
& $\begin{array}{l}\text { - Set a goal and deadline for each (new) action item } \\
\text { deadline }\end{array}$ \\
& $\begin{array}{l}\text { - Followed up with one another as deadlines approached } \\
\text { identified goals }\end{array}$ \\
\hline Delegation [9] & - Each site recognized and understood their responsibilities to meet
\end{tabular}
their own goals as well as the larger overall team goals. Individual team members were tasked with different responsibilities as appropriate for each site.

- Newsletter writing was divided so that each Community Based Organization (CBO) authored one newsletter and the Georgetown University Medical Center team edited each issue

- New tasks were assigned based on the consultants' and advisory board members' interest

\begin{tabular}{l|c}
\hline $\begin{array}{l}\text { Effective } \\
\text { communication }[9,\end{array}$ 12] & $\begin{array}{l}\text { Structural elements of communication } \\
\text { tasks. Most calls were open to all members, including bi-weekly phone } \\
\text { calls between the principal investigator and project directors at each } \\
\text { CBO, and monthly teleconference calls with the entire study team }\end{array}$ \\
\hline
\end{tabular}

- We held separate monthly interventionist supervision telephone calls for only the interventionists and our team clinical supervisors (CC; GE). The decision to restrict these calls to only the interventionists was at the suggestion of a team member; this decision promoted confidentiality of the participants and also promoted further autonomy and sense of connection among the team interventionists

- Georgetown University Medical Center sent team emails with project updates and other items, such as webinars and articles, at least once per month to the entire study team

- Polls and team surveys were conducted as an additional means of collecting team member ideas and opinions about the implementation and progress of the project

- Annual meetings featured diverse discussion methods. Both large group discussions and small break-out sessions were organized and implemented

Process elements of communication

- Communication was conducted in an accepting, considerate environment to accommodate and value different personalities and interpersonal styles, creating balanced but diverse discussions

- Each person was asked for input during monthly teleconferences and annual meetings; each CBO site was asked for group input

- Each site shared ideas, successes, and difficulties during recruitment

- Team members were offered support and reassurance throughout the process 
Table 16.1 (continued)

\begin{tabular}{|c|c|}
\hline PCOR element & Research Democracy Approaches in the Nueva Vida Intervention \\
\hline \multirow[t]{5}{*}{$\begin{array}{l}\text { Establishment of } \\
\text { shared goals; [12] }\end{array}$} & $\begin{array}{l}\text { - Voting to identify intervention topics } \\
\text { - All team members shared a passion for improving outcomes among } \\
\text { the target population of Latina breast cancer survivors and their } \\
\text { caregivers }\end{array}$ \\
\hline & $\begin{array}{l}\text { During proposal planning and writing, team members identified } \\
\text { initial shared goals for improving quality of life among Latina breast } \\
\text { cancer survivors and their caregivers }\end{array}$ \\
\hline & $\begin{array}{l}\text { - During intervention adaptation and planning, team members voted on } \\
\text { which intervention topics were most relevant to the "core" five session } \\
\text { content areas out of eight total sessions }\end{array}$ \\
\hline & $\begin{array}{l}\text { During implementation, team members identified and acted upon } \\
\text { shared goals for recruitment; intervention implementation; and quality of } \\
\text { communication among team members and with participants, including } \\
\text { dissemination of results. These goals were determined through } \\
\text { discussions that engaged all team members }\end{array}$ \\
\hline & $\begin{array}{l}\text { - At the first intervention session with each new group, participants } \\
\text { (Latina breast cancer survivors and their caregivers) voted on topics for } \\
3 \text { sessions (out of a possible } 6 \text { elective session topics). This ensured that } \\
\text { interventions received by the participants were appropriate to their } \\
\text { interests and needs. For example, some groups consisted of caregivers } \\
\text { who were adult children of the survivors, while other groups consisted } \\
\text { of spouses or partners of the survivors }\end{array}$ \\
\hline $\begin{array}{l}\text { Establishment of } \\
\text { mutual trust [12] }\end{array}$ & $\begin{array}{l}\text { - Site principal investigators emphasized mutual trust and were } \\
\text { receptive and responsive to difficulties encountered by team members } \\
\text { without causing fear of penalty or embarrassment, thus promoting a } \\
\text { culture of transparency with meeting expectations }\end{array}$ \\
\hline \multirow[t]{3}{*}{$\begin{array}{l}\text { Promotion of team } \\
\text { pride [9] }\end{array}$} & $\begin{array}{l}\text { - A team logo and motto were developed as a team and used in team } \\
\text { materials across sites }\end{array}$ \\
\hline & $\begin{array}{l}\text { - Each phone, email, or meeting communication began with sharing } \\
\text { team or individual members' study-related accomplishments }\end{array}$ \\
\hline & $\begin{array}{l}\text { - A private Facebook page allowed sharing of articles and photos } \\
\text { documenting team successes }\end{array}$ \\
\hline \multirow[t]{8}{*}{$\begin{array}{l}\text { Fostering creativity } \\
\text { and innovation [9] }\end{array}$} & $\begin{array}{l}\text { - Created a basic study structure that could easily be adapted based on } \\
\text { team member feedback and community interactions } \\
\text { - Team members suggested that the research be prioritized over } \\
\text { peripheral tasks or that requests be made in smaller, more manageable } \\
\text { steps }\end{array}$ \\
\hline & - Created a press kit based on one site's previous experience \\
\hline & - Gifts sent to participants were chosen as a team \\
\hline & - Changed newsletter format and delivery \\
\hline & - Created an introductory video used for participant recruitment \\
\hline & - Sites hosted events to accomplish a number of goals to: \\
\hline & $\begin{array}{l}\text { (a) Educate the desired target population about the importance of } \\
\text { clinical research }\end{array}$ \\
\hline & $\begin{array}{l}\text { (b) Share the outcomes of the research as a way to disseminate results } \\
\text { and show the research team's appreciation for participant involvement }\end{array}$ \\
\hline
\end{tabular}


Table 16.1 (continued)

\begin{tabular}{|c|c|}
\hline \multirow[t]{2}{*}{ PCOR element } & Research Democracy Approaches in the Nueva Vida Intervention \\
\hline & $\begin{array}{l}\text { (c) Encourage participants and team members to feel proud of how } \\
\text { their engagement made success possible }\end{array}$ \\
\hline & $\begin{array}{l}\text { (d) Provide participants an opportunity to share what important things } \\
\text { they learned in the process and what ideas they had for future research }\end{array}$ \\
\hline & $\begin{array}{l}\text { - Creative thinking helped clarify consultant roles and responsibilities. } \\
\text { For example, one consultant with expertise in clinical aspects of } \\
\text { supporting caregivers was invited to facilitate a discussion about } \\
\text { caregiver needs in a conference call and to provide an update to the team } \\
\text { during one of our annual team meetings }\end{array}$ \\
\hline & $\begin{array}{l}\text { - At a recruiter's suggestion, we created a 'recruitment flipbook' that } \\
\text { consisted of photos only (no text) to convey steps of study involvement } \\
\text { for community members with low literacy }\end{array}$ \\
\hline & $\begin{array}{l}\text { - Created a media engagement plan provided by a site PI who was a } \\
\text { former news reporter }\end{array}$ \\
\hline \multirow[t]{3}{*}{$\begin{array}{l}\text { Seeking } \\
\text { partnership } \\
\text { synergy }[13,14]\end{array}$} & $\begin{array}{l}\text { Two sites in New York hosted an event emphasizing the importance } \\
\text { of Latino participation in cancer research. Two other sites adopted that } \\
\text { idea and hosted an event in the DC metropolitan area }\end{array}$ \\
\hline & $\begin{array}{l}\text { - One CBO site principal investigator shared that work on the PCORI } \\
\text { Nueva Vida Intervention generated greater internal team cohesiveness. } \\
\text { Other team members (a CBO site principal investigator; advisory board } \\
\text { member) identified and followed through on opportunities to submit an } \\
\text { abstract as first author and co-present an invited presentation }\end{array}$ \\
\hline & $\begin{array}{l}\text { One site had its entire team complete HIPAA and Human Subjects } \\
\text { Research training }\end{array}$ \\
\hline \multirow{4}{*}{$\begin{array}{l}\text { Promotion and } \\
\text { practice of cultural } \\
\text { humility [13] }\end{array}$} & $\begin{array}{l}\text { - Some research team members acknowledged lack of familiarity with } \\
\text { cultural norms }\end{array}$ \\
\hline & $\begin{array}{l}\text { - Some community partners acknowledged lack of familiarity with } \\
\text { research }\end{array}$ \\
\hline & $\begin{array}{l}\text { The minimum inclusion age was changed from } 21 \text { (often the norm in } \\
\text { research studies) to } 18 \text { when we realized that young caregivers are } \\
\text { common among the patient population }\end{array}$ \\
\hline & $\begin{array}{l}\text { - Stopped using the word "study" when publicizing and recruiting, } \\
\text { because community partners informed us that the word "study" elicited } \\
\text { images of blood being drawn }\end{array}$ \\
\hline \multirow[t]{4}{*}{$\begin{array}{l}\text { Connecting your } \\
\text { team to resources } \\
{[9]}\end{array}$} & $\begin{array}{l}\text { Provided human subjects training to community partners using } \\
\text { CERTification, a training approved by our IRB that is designed for } \\
\text { community-based partners; adapted training into Spanish }\end{array}$ \\
\hline & - Included professional development opportunities in team emails \\
\hline & $\begin{array}{l}\text { - Leveraged existing meeting schedules to maximize learning } \\
\text { opportunities and make attendance more convenient. For example, one } \\
\text { annual meeting was scheduled around the National Latino Cancer } \\
\text { Summit and another was scheduled around a survivorship conference in } \\
\text { DC }\end{array}$ \\
\hline & $\begin{array}{l}\text { Minimized administrative burdens such as secure file sharing across } \\
\text { sites. Ultimately we simplified data requests and input from site team } \\
\text { members and increased data input among the Georgetown PI's study } \\
\text { team to lessen CBO team member burden }\end{array}$ \\
\hline
\end{tabular}


Table 16.2 Team member satisfaction and experiences survey results

\begin{tabular}{l|l}
\hline $\begin{array}{l}\text { Item text } \\
\begin{array}{l}\text { Please circle a response to indicate if the following } \\
\text { changes have occurred since joining the team: }\end{array}\end{array}$ & $\begin{array}{l}\text { \% of team members who reported } \\
\text { "increased" }\end{array}$ \\
\hline My willingness to express my point of view has increased & 45 \\
\hline Trust between the group members has increased & 81 \\
\hline $\begin{array}{l}\text { Please circle a response below to indicate your level of } \\
\text { satisfaction with the following: }\end{array}$ & $\begin{array}{l}\text { \% of team members who reported } \\
\text { "satisfied" or "extremely } \\
\text { satisfied" }\end{array}$ \\
\hline The impact of study involvement on my agency & 100 \\
\hline The amount of influence I have over team decisions & 95 \\
\hline $\begin{array}{l}\text { Based on your experience with the Nueva Vida } \\
\text { Intervention study, please circle a response to indicate } \\
\text { how likely are you to: }\end{array}$ & $\begin{array}{l}\text { \% of team members who reported } \\
\text { "likely" or "extremely likely" }\end{array}$ \\
\hline Collaborate in other research & 100 \\
\hline Seek out new research collaborations & 100
\end{tabular}

Table 16.3 Barriers identified during work on the Nueva Vida Intervention study

\begin{tabular}{|c|c|}
\hline Category & Barrier \\
\hline \multirow[t]{3}{*}{ Communication } & $\begin{array}{l}\text { "Organizational barriers/limitations to understanding/complying with research } \\
\text { practices and communicating to potential participants" }\end{array}$ \\
\hline & $\begin{array}{l}\text { "Labor intensive, [lack of] clarity in startup conversations, time [zone] } \\
\text { difference[s]" }\end{array}$ \\
\hline & "Staff mobility and communication issues" \\
\hline \multirow[t]{2}{*}{ Recruitment } & "Recruitment and retention barriers were expected" \\
\hline & "[Difficulty with] Caregiver recruitment" \\
\hline \multirow[t]{3}{*}{ Other } & "Some language barriers but resolved" \\
\hline & "Progression of disease as a hindrance to participation" \\
\hline & "[Difficulty understanding and accepting] Randomization" \\
\hline
\end{tabular}

Table 16.4 Benefits identified during work on the Nueva Vida Intervention study

\begin{tabular}{|c|c|}
\hline Category & Benefits \\
\hline \multirow[t]{4}{*}{ Collaboration } & "Collaboration" \\
\hline & "Collaboration with other subcontractors" \\
\hline & $\begin{array}{l}\text { "Wonderful collaboration, organizational structure and team } \\
\text { spirit" }\end{array}$ \\
\hline & $\begin{array}{l}\text { "Collaboration with other organizations and working with Kristi } \\
\text { [Graves] and her team" }\end{array}$ \\
\hline \multirow[t]{3}{*}{$\begin{array}{l}\text { Learning about the research } \\
\text { process }\end{array}$} & $\begin{array}{l}\text { "Internal abilities to collect and disseminate lessons learned } \\
\text { throughout the research process }\end{array}$ \\
\hline & "[Ability to] Participate in research study" \\
\hline & "Great model for staff to learn how such a project works" \\
\hline \multirow[t]{4}{*}{ Other } & "Could not be happier!" \\
\hline & $\begin{array}{l}\text { "I feel my work with A[frican] A[merican] community and other } \\
\text { advocacy work contributes" }\end{array}$ \\
\hline & "Closer connection with all sites" \\
\hline & "Learning about caregiving" \\
\hline
\end{tabular}




\section{Results}

Table 16.1 illustrates how we applied elements of PCOR using research democracy approaches during the randomized controlled trial to evaluate the Nueva Vida Intervention. We identified these elements based on evidence from studies of employee engagement, team engagement, and community-based participatory research $[13,14]$.

During the study period at one of the annual in-person team meetings, we administered a survey to assess team member satisfaction and experiences (see Table 16.2 for a summary of survey results). Team member feedback on this survey helped set the agenda and procedures for upcoming team calls. We specifically asked for barriers and benefits to individual team member's success and involvement with the study. By eliciting input during open communication on team calls and also through a survey, we obtained feedback about team procedures so that adjustments could be made, as needed. We presented results to team members to promote transparency and open communication. Team members identified barriers (Table 16.3) and benefits (Table 16.4) during the Nueva Vida Intervention Study.

Sites also reported enhanced team engagement within their own organizations. One site principal investigator reported that participation in the project contributed to restructured roles, unified people as a team pursuing a common goal, and fostered creativity and collaboration. The methods used to promote team engagement thus appeared to be advantageous not only for the larger research team but also for the individual community-based organizations. A critical component to whether partners on a research team can thrive involves recognition of their time and expertise through appropriate compensation for time and inclusion in the dissemination of results.

\section{Discussion}

Research democracy, a process by which all members of a research team (patients, CBOs, scientific investigators, and other stakeholders) are engaged, valued, respected, and heard through both direct voting and open communication, resulted in a successful PCOR project, the Nueva Vida Intervention study. The management strategies employed kept the study running efficiently and effectively and established mutual trust. Setting clear expectations provided opportunities to foster such trust, and listening to team member concerns promoted transparency and sharing of information in a safe environment. Transparency and effective communication alerts a site to events occurring at other sites which may disrupt study flow such as staff turnover, staff illness, site moves, or other obligations. Team cohesion, developed using the elements of team engagement, generated enthusiasm for the research project among the team members. The diversity of the team was an asset, contributing to the goals of team members individually and the research project as a whole. 
For example, flexibility during implementation of the study and dissemination of information to the community was particularly important, because the CBOs were more familiar with the community and culture than the researchers. Elements of team engagement that value each person may be more likely to promote community members' participation in future research. These preliminary results suggest that active application of research democracy elements may promote team engagement and satisfaction as well as awareness of project barriers and benefits, which may, in turn, strengthen and promote PCOR. Future research can systematically explore approaches for how to best assess team engagement to strengthen and promote PCOR.

\section{References}

1. Frank L, Forsythe L, Ellis L, Schrandt S, Sheridan S, Gerson J, et al. Conceptual and practical foundations of patient engagement in research at the patient-centered outcomes research institute. Qual Life Res. 2015;24(5):1033-41.

2. Wadekar M, Sharma A, Battaglia G. Patient-Centered Outcomes Research (PCOR): how can we optimize outcomes in CNS research? Innov Clin Neurosci. 2015;12(3-4):27-31.

3. Halladay JR, Donahue KE, Sleath B, Reuland D, Black A, Mitchell CM, et al. Community advisory boards guiding engaged research efforts within a clinical translational sciences award: key contextual factors explored. Prog Community Health Partnersh. 2017;11(4):367-77.

4. Dowling B, Powell M, Glendinning C. Conceptualising successful partnerships. Health Soc Care Community. 2004;12(4):309-17.

5. Bakker AB, Demerouti E. Towards a model of work engagement. Career Dev Int. 2008;13(3): 209-23.

6. Bakker AB, Demerouti E. The job demands-resources model: state of the art. J Manag Psych. 2007;22(3):309-28.

7. Lowe G. How employee engagement matters for hospital performance. Healthc Q. 2012;15(2): 29-39.

8. Torrente P, Salanova M, Llorens S, Schaufeli WB. Teams make it work: how team work engagement mediates between social resources and performance in teams. Psicothema. 2012; 24(1):106-12.

9. Jeve YB, Oppenheimer C, Konje J. Employee engagement within the NHS: a cross-sectional study. Int J Health Policy Manag. 2015;4(2):85-90.

10. Ramos V. 10 tips for building strong and engaged action teams. Updated Jan 2016. http:// everyday-democracy.org/tips/10-tips-building-strong-and-engaged-action-teams. Accessed 29 Jan 2016.

11. Vaughn LM, Busch MD. Partnering with insiders: a review of peer models across communityengaged research, education and social care. Health Soc Care Community. 2018;26(6):769-86.

12. Mitchell P, Wynia M, Golden R, McNellis B, Okun S, Webb CE, et al. Core principles \& values of effective team-based health care. Updated Oct 2012. https://www.nationalahec.org/ pdfs/vsrt-team-based-care-principles-values.pdf. Accessed 29 Jan 2016.

13. Minkler M. Community-based research partnerships: challenges and opportunities. J Urban Health. 2005;82(2 Suppl 2):ii3-12.

14. Rush CL, Darling M, Elliott MG, Febus-Sampayo I, Kuo C, Munoz J, et al. Engaging Latina cancer survivors, their caregivers, and community partners in a randomized controlled trial: Nueva Vida intervention. Qual Life Res. 2015;24(5):1107-18. 
Open Access This chapter is licensed under the terms of the Creative Commons AttributionNonCommercial 4.0 International License (http://creativecommons.org/licenses/by-nc/4.0/), which permits any noncommercial use, sharing, adaptation, distribution and reproduction in any medium or format, as long as you give appropriate credit to the original author(s) and the source, provide a link to the Creative Commons license and indicate if changes were made.

The images or other third party material in this chapter are included in the chapter's Creative Commons license, unless indicated otherwise in a credit line to the material. If material is not included in the chapter's Creative Commons license and your intended use is not permitted by statutory regulation or exceeds the permitted use, you will need to obtain permission directly from the copyright holder.

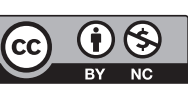

